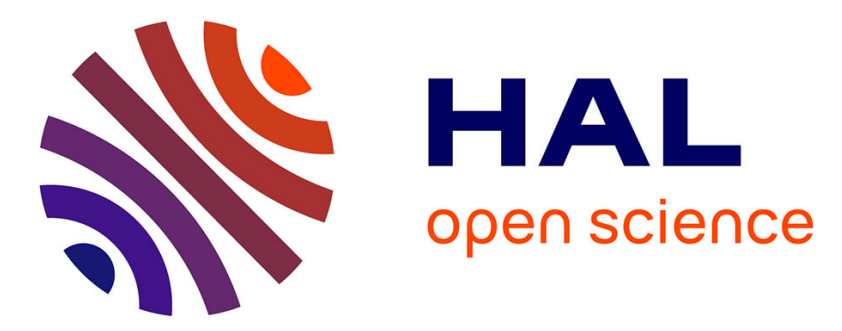

\title{
Thin current sheets and the associated wave activity observed by Solar Orbiter
}

Daniel Graham, Yuri Khotyaintsev, Konrad Steinvall, Andris Vaivads, Milan

Maksimovic, Niklas Edberg, Erik Johansson, Anders Eriksson, Matthieu

Kretzschmar, Thomas Chust

\section{To cite this version:}

Daniel Graham, Yuri Khotyaintsev, Konrad Steinvall, Andris Vaivads, Milan Maksimovic, et al.. Thin current sheets and the associated wave activity observed by Solar Orbiter. EGU General Assembly 2021, Apr 2021, online, France. 10.5194/egusphere-egu21-15860 . hal-03215712

\section{HAL Id: hal-03215712 \\ https://hal.sorbonne-universite.fr/hal-03215712}

Submitted on 3 May 2021

HAL is a multi-disciplinary open access archive for the deposit and dissemination of scientific research documents, whether they are published or not. The documents may come from teaching and research institutions in France or abroad, or from public or private research centers.
L'archive ouverte pluridisciplinaire HAL, est destinée au dépôt et à la diffusion de documents scientifiques de niveau recherche, publiés ou non, émanant des établissements d'enseignement et de recherche français ou étrangers, des laboratoires publics ou privés. 
EGU21-15860

https://doi.org/10.5194/egusphere-egu21-15860

EGU General Assembly 2021

(c) Author(s) 2021. This work is distributed under

the Creative Commons Attribution 4.0 License.

\section{Thin current sheets and the associated wave activity observed by Solar Orbiter}

Daniel Graham ${ }^{1}$, Yuri Khotyaintsev ${ }^{1}$, Konrad Steinvall ${ }^{1}$, Andris Vaivads ${ }^{2}$, Milan Maksimovic ${ }^{3}$, Niklas Edberg ${ }^{1}$, Erik Johansson ${ }^{1}$, Anders Eriksson ${ }^{1}$, Matthieu Kretzschmar ${ }^{4}$, Thomas Chust ${ }^{5}$, and the RPW, MAG and SWA Solar Orbiter teams*

${ }^{1}$ Swedish Institute of Space Physics, Uppsala, Sweden (dgraham@irfu.se)

${ }^{2}$ KTH Royal Institute of Technology, Stockholm, Sweden

${ }^{3}$ LESIA, Observatoire de Paris, Université PSL, CNRS, Sorbonne Université, Univ. Paris Diderot, Sorbonne Paris Cité

${ }^{4}$ LPP, CNRS, Ecole Polytechnique, Sorbonne Université, Observatoire de Paris, Université Paris-Saclay, PSL Research University, Palaiseau, Paris, France

${ }^{5}$ LPC2E, CNRS, 3A avenue de la Recherche Scientifique, Orléans, France

${ }^{*}$ A full list of authors appears at the end of the abstract

Thin current sheets are routinely observed in the solar wind. Here we report observations of thin current sheets and the associated plasma waves using the Solar Orbiter spacecraft. The Radio and Plasma Waves (RPW) instrument provides high-resolution measurements of the electric field, number density perturbations, and magnetic field fluctuations, which we use to identify and characterise the observed waves, while the magnetic field provided by the MAG instrument is used to characterise the current sheets. We discuss the role of current sheets in the generation of the observed waves and the effects of the waves on the current sheets.

RPW, MAG and SWA Solar Orbiter teams: S.D. Bale, V. Krasnoselskikh, E. Lorfèvre, D. Plettemeier, J. Souček, M. Steller, Š. Štverák, P. Trávníček, A. Vecchio, T. Horbury, H. O’Brien, V. Angelini, V. Evans, C. J. Owen, P. Louarn, A. Fedorov 